\title{
Case for diagnosis. A bluish nodule on the scalp*
}

\author{
Sylvia Aide Martinez-Cabriales ${ }^{1}$ \\ Jorge Ocampo-Candiani ${ }^{1}$
}

DOI: http:/ /dx.doi.org/10.1590/abd1806-4841.20175861

\author{
Ivette Miranda-Maldonado ${ }^{2}$
}

\section{CASE REPORT}

A 32-year-old man was seen due to a 24-month history of an asymptomatic nodular lesion in the left parietal region. Physical examination revealed a smoothly bluish elevated nodule of $1.5 \mathrm{~cm}$ $x 1 \mathrm{~cm}$. He reported no preceding history of trauma. Dermoscopy revealed a homogeneous blue pattern (Figure 1). The tumor was surgically excised and sent for dermatopathological study. Histological examination showed a circumscribed dermal tumor without epidermal attachment. Ductal differentiation, several cysts, and
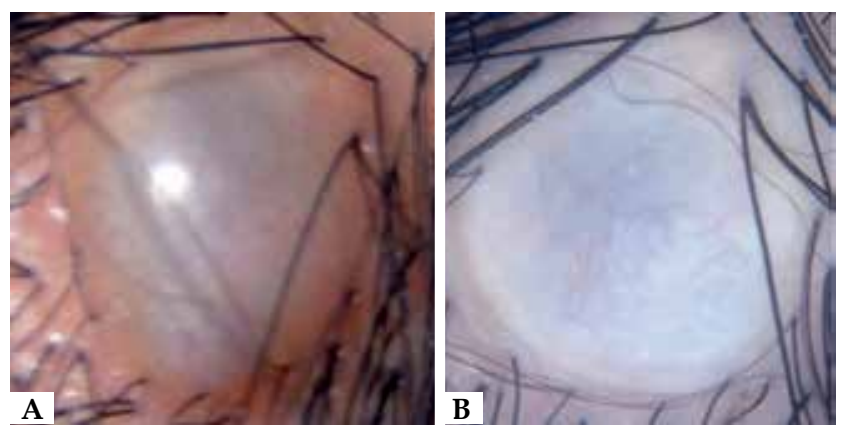

Figure 1: Clinical features. (A) Dome-shaped exophytic nodule of shiny surface and focal bluish color; (B) On dermoscopy (Dermlite ${ }^{\circledR}$ II Pro HR), a well-defined whitish nodule with focal homogeneous bluish linear area exhibiting some arborizing vessels nests of cells in hyalinized stroma were found. The tumor showed polygonal cells, mucinous cells, glycogen-rich clear cells, and ductal differentiation (Figure 2).

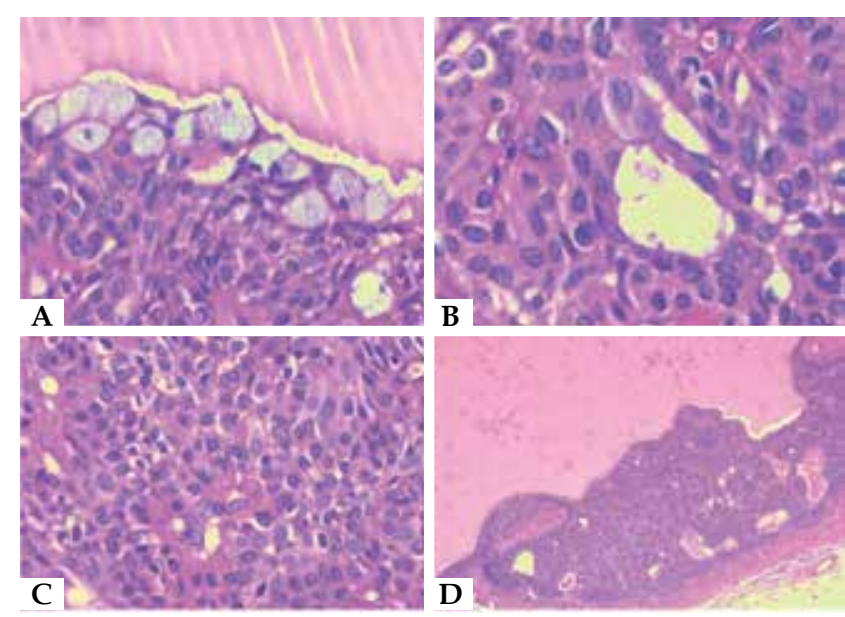

Figure 2: Histopathology (haematoxylin and eosin, original magnification 100x). (A) Image shows mucinous cells and big cysts; (B) Ductal differentiation with eosinophilic decapitation secretion; (C) Clear cells and polygonal cells; (D) Cystic areas filled with eosinophilic material

\section{Received on 01.04 .2016}

Approved by the Advisory Board and accepted for publication on 16.11.2016

Work performed at the Department of Dermatology, University Hospital “Dr. José Eleuterio González" of the Autonomous University of Nuevo León - San Nicolás de los Garza (N.L), México.

Financial support: none.

Conflict of interest: none.

Department of Dermatology - University Hospital “Dr. José Eleuterio González” Autonomous University of Nuevo León - Monterrey (N.L), México.

2 Department of Pathology - University Hospital “Dr. José Eleuterio González” Autonomous University of Nuevo León - Monterrey (N.L), México. 


\section{DISCUSSION}

Hidradenoma is an uncommon benign tumor of the distal portion of the sweat glands. It is suggested that this tumor most frequently arises from the apocrine glands and not from the eccrine gland as previously thought. ${ }^{1}$ Due to the uncertainty about its origin, it has received more than one name, all of them corresponding to the predominant histopathological component: clear cell hidradenoma, solid-cystic hidradenoma, clear cell myoepithelioma, and eccrine acrospiroma. ${ }^{2}$ The condition is more common in middle-aged women. Clinically, it presents as an asymptomatic nodule, $0.5-2 \mathrm{~cm}$ in size, and most frequently seen on the scalp, although any cutaneous site can be involved. The overlying skin usually reveals a red-brown or shinny surface, but in a few cases ulceration is seen. Dermoscopic examination shows a defined nodule with amorphous whitish and reddish-purple areas, with linear and hairpin vessels ${ }^{3}$. A case report previously documented a homogeneous blue pattern in a cystic lesion as a result of the Tyndall effect. ${ }^{4}$ Due to the vari- ability of clinical and dermoscopic features, a skin biopsy is necessary for diagnosis. On histopathology, the epidermis is frequently normal with a well-circumscribed, non-encapsulated tumor in the dermis. ${ }^{5}$ There are two types of hidradenoma, a poroid type - that shows eccrine differentiation with poroid and cuticular cells - and a nodular type - that shows apocrine differentiation with polyhedral, squamous, mucinous, and clear cells. These cells are arranged in nests in a ductal pattern. However, if they degenerate, cysts are formed. Features to identify apocrine differentiation include decapitation secretion, mucinous secretion, and sebaceous metaplasia. ${ }^{6} \mathrm{Al}-$ though immunohistochemical stains help in diagnosis confirmation - such as epithelial membrane antigen, carcinoembryonic antigen, and AE1/AE3 cytokeratin -, they are not often required. Differential diagnoses include basal cell carcinoma, metastatic tumor, cutaneous lymphoma, and other skin adnexal neoplasms. Treatment is always surgical with safety margins since $6.7 \%$ of cases present a malignant transformation. It is important to emphasize that hidradenocarcinoma looks clinically similar to hidradenoma. $\square$

Abstract: Acrospiroma, also known as hidradenoma, is a rare cutaneous tumor that has several histological characteristics. As a consequence, a high index of suspicion is necessary for its diagnosis. Here we report a case that illustrates the importance of a good clinical-pathologic correlation in order to recognize this disease.

Keywords: Acrospiroma; Neoplasms, adnexal and skin appendage; Poroma; Scalp; Scalp dermatoses; Sweat gland neoplasms

\section{REFERENCES}

1. Liu Y. The histogenesis of clear cell papillary carcinoma of the skin. Am J Pathol. 1949;25:93-103

2. Hashimoto K, DiBella RJ, Lever WF. Clear cell hidradenoma. Histological histochemical, and electron microscopic studies. Arch Dermatol. 1967;96:18-38

3. Yoshida Y, Nakashima K, Yamamoto 0. Dermoscopic features of clear cell hidradenoma. Dermatology. 2008;217:250-1.

4. Gatti A, di Meo N, Trevisan G. Dermoscopy of eccrine acrospiroma masquerading as nodular malignant melanoma. Acta Dermatovenerol Alp Pannonica Adriat. 2010;19:23-5.

5. Nandeesh BN, Rajalakshmi T. A study of histopathologic spectrum of nodular hidradenoma. Am J Dermatopathol. 2012;34:461-70.

6. Angulo J, Jaqueti G, Kutzner H, Requena L. Squamous cell apocrine hidradenoma J Cutan Pathol. 2007:34:801-3.
MAILING ADDRESS:

Sylvia Aide Martinez-Cabriales

Av. Madero and Gonzalitos $\mathrm{S} / \mathrm{N}$

64460 Mitras Centro - Monterrey, México

E-mail: sylvia.mtzcabriales@gmail.com

How to cite this article: Martinez-Cabriales SA, Miranda-Maldonado I, Ocampo-Candiani J. Case for diagnosis. A bluish nodule on the scalp An Bras Dermatol. 2017;92(2):275-6. 